\title{
Pengaruh Pijit Bayi (pe’e) Tradisional Bima Terhadap Status Gizi Bayi Usia 5-12 Bulan di Kecamatan Bolo Kabupaten Bima
}

\author{
Kurniadi $^{1(\mathrm{CA})}$, Mardiatun $^{2}$ \\ ${ }^{1(\mathrm{CA})}$ Program Studi D III Keperawatan Bima, Jurusan Keerawatan, Poltekkes Kemenkes Mataram, \\ Indonesia; Kurniadi.poltekkes@ gmail.com (Corresponding Author) \\ Program Studi D III Keperawatan Mataram, Jurusan Keerawatan, Poltekkes Kemenkes Mataram, \\ Indonesia
}

Genesis Naskah : Diterima 01 Oktober 2019;

Disetujui 12 November 2019;

Publikasi 15 November 2019

\begin{abstract}
Massage will also stimulate the vagus nerve which will produce gastrin and insulin enzymes so that absorption of the digestive tract is better, the stomach is empty faster, and the baby will be hungry more often, so the baby will suckle more often, and the end result will be an increase in baby's weight. One of the most important indicators in assessing nutritional fulfillment in infants is taking into account body weight (Zulhaida, 2003). Weight is the most important anthropometric measure, used at every opportunity to examine the health of infants in all age groups (Soetjiningsih, 1998: 38). This research is a quasiexperimental study with pre and post test designs in the same group. The researcher will assess the nutritional status of infants aged 5-12 months before and after the traditional massage (pe'e). Sampling was carried out in Bolo Subdistrict, Bima District by using Purposive sampling, which was conducted in September to November 2018 with a total sample of 140 respondents. Data was collected using an observation sheet. The results of this study found that the weight of infants aged 5-12 months before peee was in the sub-normal category, the weight of infants aged 5-12 months experienced an increase after pe'e I and pe'e II, the results of data analysis found there was an influence weight gain before and after pee is done in infants aged 5-12 months
\end{abstract}

\section{Keywords: traditional massage; nutritional status}

\begin{abstract}
ABSTRAK
Pemijatan juga akan menstimulasi nervus vagus yang akan memproduksi enzim gastrin dan insulin sehingga penyerapan saluran cerna lebih baik, lambung lebih cepat kosong, dan bayi akan lebih sering lapar, sehingga bayi akan menyusu lebih sering, dan hasil akhirnya berupa peningkatan berat badan bayi. Salah satu indikator terpenting dalam menilai pemenuhan nutrisi pada bayi adalah dengan memperhitungkan berat badan (Zulhaida, 2003). Berat badan merupakan ukuran antropometrik yang terpenting, dipakai pada setiap kesempatan memeriksa kesehatan bayi pada semua kelompok umur (Soetjiningsih, 1998:38). Penelitian ini merupakan penelitian kuasi eksperimen dengan desain pre dan post test pada kelompok yang sama. Peneliti akan menilai keadaan status gizi bayi usia 5-12 bulan sebelum dan sesudah dilakukan pijit tradisional (pe'e). Pengambilan sampel dilakukan di Kecamatan Bolo Kabupaten Bima Dengan menggunakan Purposive sampling, yang dilakukan pada September sampai Nopember 2018 dengan jumlah sample 140 responden. Data dikumpulkan dengan menggunakan lembar observasi. Hasil penelitian ini didapatkan Berat Badan bayi usia 5-12 bulan sebelum pe'e berada dalama kategori bawah normal, Berat Badan bayi usia 5-12 bulan mengalami peningkatan setelah pe'e I dan pe'e II, .Hasil analisa data didapatkan ada pengaruh peningkatan berat badan sebelum dan sesudah dilakukan pe'e pada bayi usia 5-12 bulan
\end{abstract}

Kata Kunci : pijit tradisional; status gizi 


\section{PENDAHULUAN}

Pijit bayi adalah terapi sentuh tertua dan terpopuler yang dikenal manusia. Pijit bayi telah lama dilakukan hampir di seluruh dunia termasuk di Indonesia dan diwariskan secara turun temurun. (Roesli, 2001). Salah satu indikator terpenting dalam menilai pemenuhan nutrisi pada bayi adalah dengan memperhitungkan berat badan (Zulhaida, 2003). Berkenaan dengan hal tersebut, penanganan secara nonfarmakologis terhadap peningkatan nafsu makan bayi sangat diperlukan untuk membantu meningkatkan berat badan bayi dan mencegah terjadinya kurang gizi pada bayi. Salah satu cara yang dapat diperkenalkan dan aman bagi bayi adalah pijat bayi.

Di Kabupaten Bima pijit bayi (Pe'e) merupakan tradisi budaya Bima yang dilakukan secara turun temurun oleh masyarakat Bima, sebagai upaya meminimalisir kejang pada bayi. Selain itu budaya pe'e juga dipercaya mampu meningkatkan berat badan bayi. Budaya pe'e pada masyarakat Bima berbeda dengan pijit bayi pada umumnya, pe'e pada masyarakat Bima dilakukan oleh dukun bayi dengan menggunakan rempah-rempah yang ditumbuk secara halus. Hasil penelitian terdahulu yang dilakukan oleh peneliti sendiri pada tahun 2017, dari 30 responden didapatkan pengaruh yang signifikan istrahat tidur bayi setelah dilakukan pijit tradisional Bima (pe'e). Di Kecamatan Bolo terdapat 700 bayi berusia 612 bulan, Berdasarkan studi pendahuluan dengan cara wawancara 10 orang ibu yang memiliki anak usia 5-12 bulan mengatakan nafsu makan bayi meningkat setelah dilakukan dipijit tradisional yang dilakukan oleh dukun pijit bayi. Berdasarkan uraian tersebut penulis ingin meneliti tentang "Pengaruh Pijit Bayi (PE’E) tradisional Bima terhadap status gizi bayi usia 5-12 bulan di Kecamatan Bolo Kabupaten Bima

\section{METODE}

Penelitian ini merupakan penelitian quasi eksperimen dengan desain Adapaun rancangan penelitian yang di gunakan dalam penelitian ini adalah Pretest and Postest Control Group Dessign, rancangan disusun untuk menjawab permasalahan mengenai pengaruh pe"e terhadap status gizi bayi usia 5-12 bulan di kecamatan bolo kabupaten Bima (Zainuddin, 2000)

\section{HASIL}

1. Karakteristik respoden berdasarkan berat badan sebelum Pe'e
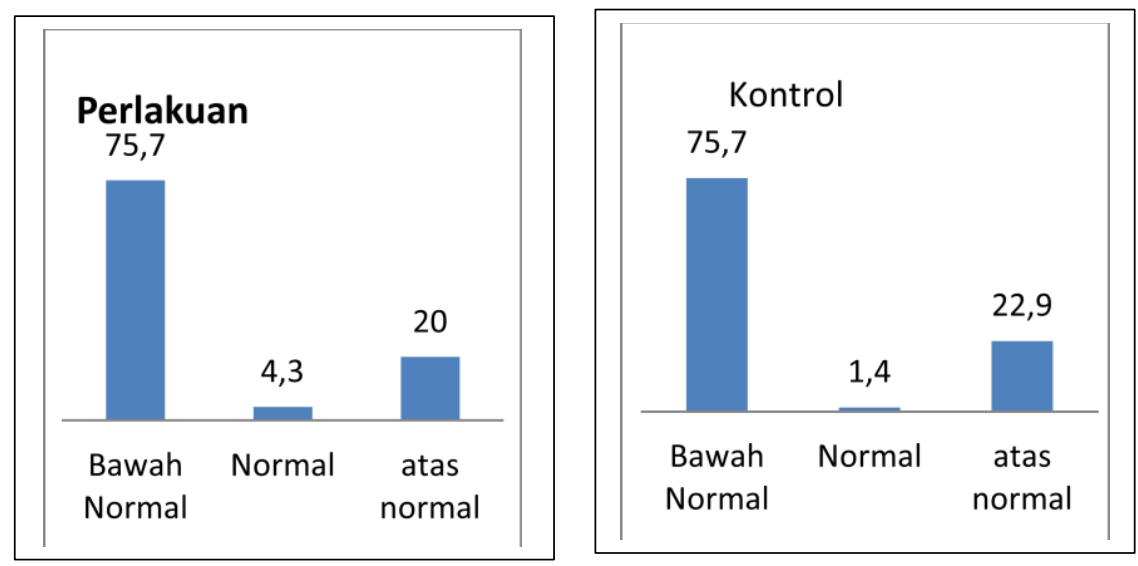

Gambar 1 : Karakteristik responden berdasarkan berat badan sebelum pe'e usia bayi 5-12 di Kecamatan Bolo Kabupaten Bima Tahun 2018 
Gambar 1 menunjukan karakteristik responden berdasarkan berat badan pada kelompok perakuan maupun kelompok kontrol sebagian besar berada dibawah normal $(75,7 \%)$.

2. Karakteristik Responden berdasarkan berat badan setelah pe'e I
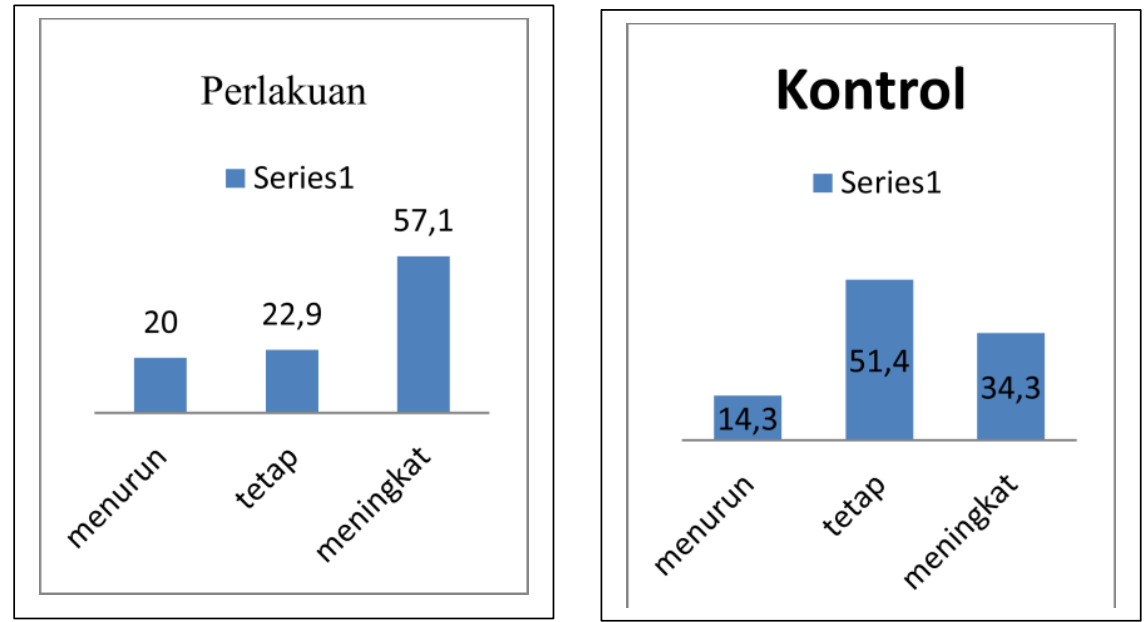

Gambar 2 : Karakteristik responden berdasarkan berat badan setelah pe'e I usia bayi 5-12 di Kecamatan Bolo Kabupaten Bima Tahun 2018

Dari gambar 2 di atas dapat dilihat bahwa karakteristik responden berdasarkan berat badan setelah pe'e I pada kelompok perakuan yang terbanyak adalah meningkat $40(57,1 \%)$ responden, sementara pada kelompok kontrol yang terbanyak adalah tetap $36(52,4 \%)$ responden.

3. Karakteristik Responden berdasarkan berat badan setelah pe'e II
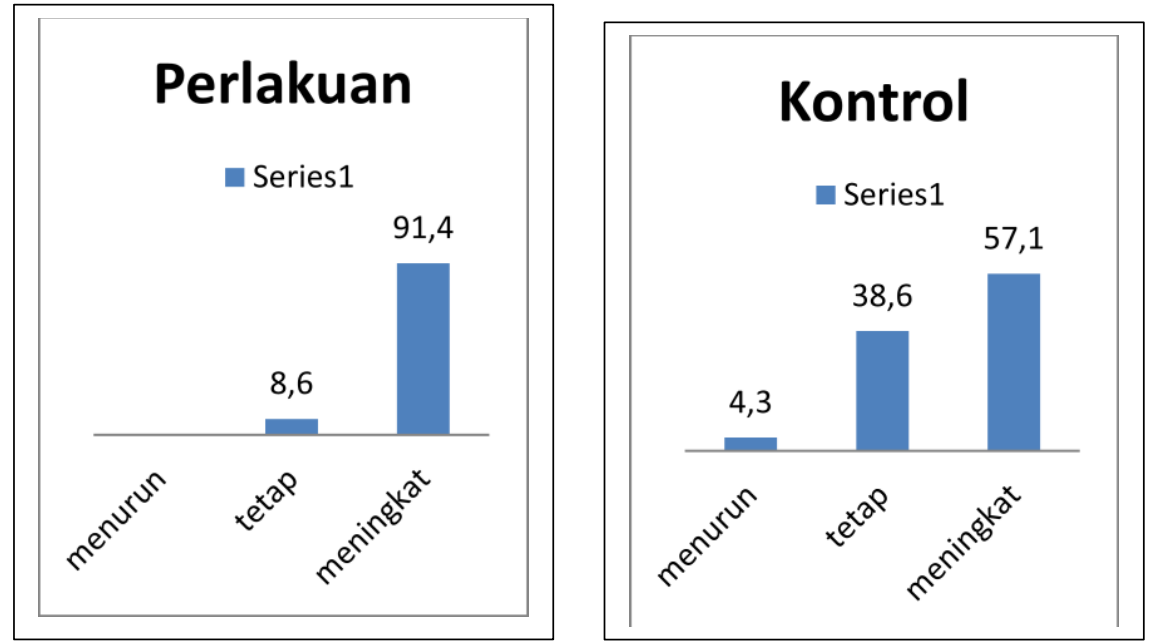

Gambar 3 : Karakteristik Responden Berdasarkan berat badan setelah pe'e II usia bayi 5-12 di Kecamatan Bolo Kabupaten Bima Tahun 2018

Gambar 3 menampilkan karakteristik responden berdasarkan berat badan setelah pe'e II kelompok perakuan yang terbanyak adalah meningkat $64(91,4 \%)$ responden, sementara pada kelompok kontrol yang terbanyak adalah tetap $40(57,1 \%)$ responden. 
4. Rerata berat badan bayi usia 5-12 bulan sebelum dan sesudah dilakukan pe'e I dan pe'e II pada kelompok perlakuan, serta berat badan pada kelompok kontrol

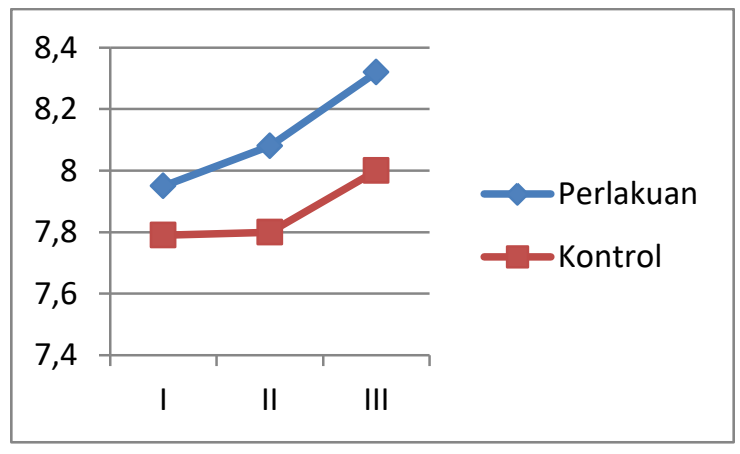

Gambar 4 : Keadaan berat badan bayi usia 5-12 bulan sebelum dan sesudah dilakukan pe'e I dan pe'e II serta berat badan Kontrol I, Kontrol II di kecamatan Bolo kabupaten Bima

Berdasarkan gambar 4 didapatkan berat badan bayi sebelum pe'e berada dalam kategori bawah normal, setelah dilakukan pe'e I terjadi peningkatan $(2,33)$, setelah dilakukan pe'e II peningkatan berat badannya semakin meningkat $(2,91)$. Sedangkan untuk kelompok perlakuan pada kontrol I berat badan berada dalam kategori bawah normal $(1,528)$, pada kotrol II meningkat menjadi 2,2, dana di kotrol III meningkat menjadi 2,528.

\section{PEMBAHASAN}

Pada penelitian ini secara uji statistik terdapat perbedaan yang signifikan antara berat badan bayi sebelum dilakukan terapi pijat degan berat badan bayi setelah dilakukan terapi pijat, dimana terjadi peningkatan berat badan untuk masing-masing bayi setelah dan berat badan bayi semakin meningkat setelah dilakukan pemijitan II. Persentase perubahan berat badan dari berat badan lahir merupakan indikator kecukupan makan. Penurunan berat badan berlebihan biasanya disebabkan oleh adanya asupan nutrisi yang tidak adekuat sebagai akibat dari pasokan susu tidak mencukupi atau pemberian susu tidak efektif. Pada bayi dengan peningkatan berat badan baik disebabkan karena beberapa faktor yang salah satunya adalah pemberian ASI eksklusif pada bayi selama 6 bulan.

Pada bayi yang memiliki berat badan menurun dapat disebabkan karena kurang terpenuhinya pemberian ASI eksklusif. Selain itu dapat juga disebabkan karena pemberian MP-ASI yang tidak sesuai dengan frekuensi yang seharusnya diberikan sehingga bayi beresiko mengalami gizi buruk. Faktor pendukung lainnya dapat disebabkan karena bayi sedang sakit. Keadaan ini sesuai Hasil penelitian Sari (2004), didapatkan bahwa bayi yang tidak dipijat mengalami peningkatan berat badan, dengan alasan peningkatan berat badan dikarenakan bayi diberi ASI secara eksklusif. Sedangkan hasil penelitian ini menunjukkan bahwa bayi yang dipijat cenderung untuk mengalami peningkatan berat badan. Hal ini dikarenakan pemijatan menyebabkan penyerapan makanan lebih baik yang mengakibatkan bayi cepat lapar dan sering menyusu akibatnya berat badan bayi cepat naik.

Terkait dengan lebih bagus peningkatan berat badan pada kelompok perlakuan bisa disebabkan karena faktor rempah-rempah yang digunakan sebagai luluran, yang salah satu isinya adalah sanatan kelapa. Dalam studi yang dilakkan oleh Sankaranarayanan et al, neonatus yang dipijat dengan minyak 
kelapa, memiliki kecepatan peningkatan pertumbuhan badan dibandingkan kelompok plasebo (bubuk) dan dalam penelitian Soriano et al, neonatus prematur yang dipijat dengan minyak kedelai, mengalami peningkatan yang signifikan. dalam parameter antropometri pada usia satu bulan dibandingkan dengan tanpa kelompok pijat. (Luke C. Mullany, et all (2006). Pijat juga dapat meningkatkan ketersediaan serotonin yang mempengaruhi kualitas tidur seseorang. Pijat juga dapat meningkatkan kadar epinefrin (adrenalin) dengan merangsang sistem saraf simpatik. Ini dapat meningkatkan kewaspadaan seseorang. Sebaliknya, pijatan yang lebih lambat, lebih dalam, dan lebih ritmis dapat, mengurangi kadar epinefrin, menciptakan perasaan rileks, dan memfasilitasi tidur nyenyak. (Alex A. Kecskes).

\section{KESIMPULAN}

Dari hasil penelitian tentang pengaruh pijit bayi (pe'e) tradisional bima terhadap status gizi bayi usia 5-12 bulan di kecamatan bolo kabupaten bima hasil analisis uji Mann-Whitney U disimpulkan bahwa hanya terdapat perbedaan berat badan bayi 5-12 bulan sebelum dan setelah pe'e II. Pe'e merupakan warisan budaya Bima yang bernilai positif dalam mengotimalkan berat badan bayi, yang keberadaanya perlu dilestarikan. Hasil penelitian ini bisa dijadikan referensi bagi profesi keperawatan, dalam rangka menyambut praktek mandiri keperawatan

\section{DAFTA PUSTAKA}

Alex A. Kecskes ( ) American Massage Therapy Association (www.amtamassage.org).

Astri sukarniati (2015), Gambaran kenaikan berat badan bayi usia 6-12 bulan di Desa Pendowoharjo kecamatan sewon kabupaten Bantul.

Behrman, R.E et. al (2003). Ilmu kesehatan anak nelson. Volume 1. Jakarta : EGC

Dahlan, M.S. (2009). Besar sampel dan cara pengambilan sampel dalam penelitian kedokteran dan kesehatan. Salemba Medika.

Dimyati, V. (2011). Anak Usia Sekolah Berisiko Anemia.hal-9.Jurnal Nasional.

Djoko, I. (2007).Panduan Gizi Lengkap Keluarga dan Olahragawan.Yogyakarta

Gibney, J., Margaretts, M., Kearney, J. \& Arab, L. (2008).Gizi kesehatan masyarakat .Jakarta:EGC.

Luke C. Mullany, ${ }^{a}$ Gary L. Darmstadt, ${ }^{\text {a }}$ Subarna K. Khatry (2006) Traditional Massage of Newborns in Nepal: Implications for Trials of Improved Practice, J Trop Pediatr

Maharani, S.(2008).Mengenali \& memahami berbagai Gangguan Kesehatan Anak.Jogjakarta:Katahati.

aharani, Sabrina. 2009. Pijat Dan Senam Sehat Untuk Bayi. Jogjakarta: Kata Hati.

Maryunani, Anik. 2010. Ilmu Kesehatan Anak dalam Kebidanan. Jakarta: Trans Info Media

Nursalam, S. \& Rekawati,U,S.(2005).Asuhan Keperawatan Bayi dan Anak (untuk perawat dan Bidan). Edisi Pertama-Jakarta:Salemba Medika.

Nursalam. (2008). Konsep dan penerapan metodologi penelitian ilmu keperawatan, pedoman skripsi, tesis dan instrumen penelitian keperawatan edisi 2. Jakarta : Salemba Medika

Putri, Alissa, 2009. Pijat dan Senam Untuk Bayi dan Balita Panduan Praktis Memijat Bayi Balita. Yogyakarta: Brilliant Offset. 